it was handed for report to I. Tarkhanov, who, after some time, presented a long scientific review of the work. However, he failed to come to any definite conclusions about it, because of the absolute newness of the subject and the absence of any literature on it. It is hoped to include the new paper in the complete edition of Pavlov's works which the Academy proposes publishing.

\section{The Linnean Society of London}

GENERAL meetings of the Linnean Society of London are to be resumed at 3 p.m. on the following Thursdays: March 6, April 3, and May 1. On March 6, several papers will be read. The centenary of the Royal Botanic Gardens, Kew, as a Government institution occurs on April 1, and at the meeting on April 3, Sir Arthur W. Hill, director of the Royal Gardens, will give some account of the work of Kew during the past hundred years. At the meeting on May 1 , the Society will keep the tercentenary of the birth of Nehemiah Grew, when Dr. Agnes Arber will give an account of him, and of Marcellus Malpighi. The anniversary meeting will be held on May 24, when the president will address the Society. The council is to consider the possibility of prolonging the session into June and July.

\section{Announcements}

OwnNa to the generosity of the Rockefeller Foundation, which has provided a grant for the purpose, the Royal Society is in a position to give some assistance to scientific societies and associations which, as a result of war conditions, are experiencing financial difficulties in the publication of scientific journals.

AMONG the bequests in the will of the late Sir Robert Hadfield, who died on September 30 last, are the following : gold and other medals, diplomas and certificates to the University of Sheffield for any library or museum in connexion with the Faculty of Metallurgy, and failing acceptance, to the Science Museum, South Kensington; his collection of alloy specimens forming the record of his various papers to scientific and technical societies to the Science

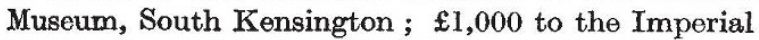
Cancer Research Fund; $£ 1,000$ to the Royal Society for general research work.

Dr. J. BuRTr Davy, late University demonstrato $r$ in forestry in the University of Oxford, who died on August 20, bequeathed a bond for $£ 7,000$, secured on property in the Transvaal, or any of the capital paid, to the Chancellor, masters, and scholars of the University of Oxford, to found a scholarship, "The Burtt-Davy Research Scholarship", for research work in taxonomic botany and/or tropical plant ecology.

THE University of Liverpool is to receive a sum of $£ 2,500$, under the will of Mrs. Mary Harmood Hamilton, to endow a scholarship or scholarships in the Faculty of Engineering.

SrR ANDREw Davidson, county medical officer for the North Riding of Yorkshire, has been appointed to succeed Prof. J. Mackintosh as chief medical officer of the Scottish Department of Health.
Mr. Hector Leak has been appointed president of the Royal Statistical Society, to hold office until the next annual general meeting, in succession to the late Mr. Henry W. Macrosty (see p. 230 of this issue).

Mr. George Grant, registrar of University College, Southampton, since 1923, has been appointed registrar of the University of Birmingham to succeed the late Mr. D. J. Cameron. The status and stipend of registrar have been raised to equality with those of full-time professors.

THE journal Microentomology, issued from the Natural History Museum of Stanford University (California), is now in its fifth volume. Among recent issues that have come to hand are contributions by Dr. G. F. Ferris and others on the detailed external morphology of selected types of the various orders of insects. These accounts are very clearly illustrated by well-executed figures that are intended to meet deficiencies in this respect in many existing publications. The journal, it may be added, is obtainable from the Director of the Museum, and individual parts are obtainable separately at a low price.

Durrng the committee stage in the House of Commons of the War Damage Bill, Sir William Jowitt said, in reply to an amendment put forward by Mr. K. W. M. Pickthorn, one of the representatives of the University of Cambridge, that universities must be regarded, for the purpose of the Bill, as carrying on business. That being so, they would not be exempt from compulsory insurance, but he added that the Government would use its powers under the clause to exempt from the obligation to insure certain classes of the non-essential equipment of universities. He expressed the hope that the Government would receive assistance from the universities and their representatives in formulating a workable scheme.

A cataloque of books relating to Egypt recently issued by Mr. George Salby, oriental bookseller, of 65 Great Russell Street, London, W $` .1$, has a special association interest for Egyptologists and students of the archrology of the Middle East. It includes the libraries of two well-known archæologists. First that of J. L. Starkey, excavator of Lachish, whose assassination by an Arab brought to a premature close one of the most illuminating of recent archæological excavations in Palestine; and secondly, that of Alan W. Shorter, assistant keeper of the Department of Egyptian and Assyrian Antiquities in the British Museum, whose early death cut short a career of much promise. In addition to books which might be termed the tools of a working archiologist, the catalogue includes a number of rarities, among them Prisse d'Avennes "L'Art Arabe", text with three volumes of 200 plates, Rosellini's "Monuments of Egypt and Nubia", and Arthur Upham Pope and Phyllis Ackerman's "A Survey of Persian Art from Prehistoric Times to the Present", the last-named a monumental and scholarly production.

Erratum. In the letter "Rheology of Plastic Materials" in NATURE of February 8, p. 176, for the formula " $\psi=S \sigma^{4} \ell^{k}$ " $\operatorname{read} " \psi=S \sigma^{-1} t^{k}$ ". 